International Research Journal of Management, IT \& Social Sciences
Available online at https://sloap.org/journals/index.php/irjmis/
Vol. 6 No. 6, November 2019, pages: 29 36
ISSN: 2395-7492
https://doi.org/10.21744/irjmis.v6n6.746

\title{
Social and Cultural Shifts on Art Worker Community Towards Current Globalization
}

I Nengah Merta

Article history:

Received: 27 May 2019

Accepted: 31 July 2019

Published: 20 September 2019

Keywords:

art;

cultural shift;

globalization;

social;

workers;

\begin{abstract}
The purpose of this study is to find out and describe the social and cultural shifts of the art worker community due to the current of globalization in the Junjungan village of Ubud, Bali. Advances in technology and information are very fast causing all components of life to experience a shift both social and cultural Junjungan Ubud people began to experience a very drastic shift along with changes in human civilization at this time. This study uses a qualitative descriptive method, using proportional sampling techniques consisting of arts workers and the community who work in the tourism sector in the village of Junjungan Ubud, Bali. The social and cultural shift of the people of Junjungan Ubud Village in Bali is inseparable from the embryo of globalization that is felt in all sectors of people's lives. Globalization is the spread of certain values and cultures throughout the world. Globalization which makes the world smaller is seen in terms of human interaction due to the development of technological science, art and information holistically. Things that need to be improved gradually and consistently in the form of human resource management through competitive vocational education with other ASEAN friendly countries.
\end{abstract}

\section{Author correspondence:}

I Nengah Merta,

Wira Bhakti Denpasar College, Denpasar, Indonesia

Jalan Cempaka No. 6 Denpasar 89233, Phone: +62 82247303361,

Email: nengahwirabhakti@gmail.com

\section{Introduction}

Social and cultural change in Bali is different from social and cultural changes in general that occur in various countries. Generally, the change from the primary sector goes to the secondary sector and only then leads to the tertiary sector. Bali's social changes immediately jumped from the primary sector to the tertiary sector. This change is limited in terms of potential so it is not possible for large-scale industrial development, it is also influenced by the rapid development in all fields, especially the tourism sector. The impact of tourism development began to be felt, namely the economic rate that began to increase (Lindayani et al., 2018). Besides that, the shift in the social and cultural sector in the

${ }^{a}$ Wira Bhakti Denpasar College, Denpasar, Indonesia 
Junjungan Ubud community was seen from the community singing or harvesting rice together that had not been seen anymore or became extinct because of the social shift affected by the development of tourism. Producing works of art has become one of the cornerstones of the life of the people of Junjungan Ubud Bali Village in improving their standard of living and this must be fought for continuously. The arts produced are coordinated by galleries located around Ubud, Mas, and Peliatan. Furthermore, this work of art has been ordered by foreign businessmen abroad by sending some art goods in containers that are accounted for by exporters. This is the importance of the embodiment of tourism development that cannot be denied, the development of the tourism sector does indeed bring jobs and increase income for the people of Junjungan Ubud Bali, this is then expected to improve the quality of life of the people. It should be noted, be aware that the tourism sector can expand business opportunities and increase the income of the people of Junjungan Ubud and the surrounding area. With the establishment of tourism as one of the leading sectors of the national economy by targeting 20 million tourists with an estimated income of around IDR 260 trillion, the Minister of Tourism on several occasions often said "Tourism is the future of Indonesia". The statement then leads to the question, then, how is the role of tourism in contributing to increasing social welfare and preserving culture? Based on the above phenomena the main issues can be formulated as follows:

1) How is the social and cultural shift due to the current of globalization in the village of Junjungan Ubud, Bali?

2) How to minimize the impact of social and cultural shifts so that the community Can art workers survive the current of globalization?

\section{Literature Review}

Case studies of social changes that occur in society in the face of globalization have been widely studied by local and foreign researchers. However, research on the Social and Cultural Shifts of the Art Worker Community Due to the Current of Globalization in Junjungan Village, Ubud, Bali, is interesting to study for research findings.

Qomarudin (2010), entitled Social change and the role of the community in developing the Karimun Jawa island tourism area. The objectives of this study are: (1) to find out the process of developing the Karimun Jawa tourism area, (2) the impact of the development of the Karimunjawa tourism area on social change in the community, and (3) knowing the role of the community in carrying out the development of the Karimun-Java tourist area. The research method used is a qualitative method with a focus on the development of the Karimun Jawa tourism area and all community activities related to the development of the Karimun Jawa tourism area. Research data were collected through observation, interview, and document study techniques. Data objectivity test is done by method triangulation technique. Data analysis was performed using a flow analysis model. The results showed that social change has always occurred in the community, including in the development of the Karimun Jawa Islands tourist area, including an increase in income, a progressive mindset as a result of interactions with tourists, increased awareness to protect the ecosystems that exist in the tourist area. While the negative impact of which is the changing lifestyle of togetherness into materialism and individualism, the higher level of pollution as a result of tourism and development is not felt by all levels of society in Karimun Jawa. The role and society in the development of tourism areas are not optimal and is highly dependent on social characteristics and the culture of the community, the economic characteristics of the community and the availability of infrastructure and the central area of development (Aditya \& Kusuma, 2019).

Furthermore, Fitriani Nia (2017), with the title Social Change in Community Culture (Case Study of the Shoe and Sandal Industry in Kampung Sindang Barang, Pasir Eurih Village, Taman Sari District, Bogor Regency.

This study aims to obtain data on the background of shifting people's livelihoods to the shoe and sandal industry sector in Sindangbarang, the underlying factors and the socio-cultural changes that occur as a result of the shoe and sandal industry that developed in Sindangbarang. This research was carried out in Sindang Barang Village, Pasir Eurih Village, Taman Sari District, Bogor Regency. The research method used in this study is a qualitative method, with data collection techniques through observation, interviews, and documentation. The results of this study are the changes in the livelihoods of the Sindang community. Goods from farming to shoe craftsmen are caused by the entry of the footwear and sandals industry into Sindangbarang. There are factors that support the transition of the Sindanbarang community's livelihoods, namely internal factors, and external factors. As a result of the shift in livelihoods, social and cultural changes have occurred in the Sindanbarang community. Changes that occur are very visible in the attitude of a more individualistic society, changes in traditions and ancestral values of the people of Sindanbarang and changes in belief. The waning of mutual cooperation culture in the community and the attitude and lifestyle of the Sindang goods community has become more modern like the urban community. Seen with a high level of work ethic, high work competition, and individualist attitudes. From the two studies above, this study differs in terms of the location of the study, the variables used and the results of the discussion (Aini, 2017; Jain et al., 2017). 


\section{Materials and Methods}

\section{Data Types and Sources}

The data used in this study are:

1) Primary data, i.e. data and information obtained directly from sources/respondents. This data was obtained by conducting interviews with several art workers in the village of Junjungan Ubud. By using proportional sampling technique with a sample of 9 arts workers and 20 people of tourism workers.

2) Secondary data, i.e. supporting data and information obtained from the Junjungan Ubud Bali office.

\section{Research model specifications}

Theories of social change from Karl Max in Yuman (2017). Theory of Social Change is a natural thing and will continue as long as humans interact and socialize. Social change occurs because of changes in elements in people's lives, both material and immaterial, as a way to maintain the balance of society and adapt to the development of a dynamic era. For example, geographic, biological, economic, or cultural elements. Sociologists argue that social change is the main social condition that causes social change. These conditions include economic, technological, geographical or biological conditions. This condition causes changes in other aspects of social life. Social change has a direction the community must go. All societies go through the same phase sequence and start from the initial development stage to the last development (Wirawan, 2018).

Globalization Theory Barbara Ward in Warsono (2007). Globalization as a global process is characterized by the increasing loss of world borders (a borderless world: one world, different but never divide), inseparable from the development of human thought. Changes in the world and culture, more due to the thought of the demonstration movement (Ward, 2013 in Warsono, 2007). Economic globalization is a process of economic activity and trade, in which countries around the world become a market force that is increasingly integrated with no obstacles to the country's territorial borders (Abeng, 1997). Economic globalization requires the removal of all restrictions and barriers to the flow of capital, goods, and services. When economic globalization occurs, the boundaries of a country will become blurred and the link between the national economy and the international economy will be even tighter.

\section{Research sites}

The location of this research is in the village of Junjungan Ubud, Bali by observing and mapping measurable community activities. The observation time as the object of analysis is the condition of 12 (twelve) months from January to December running in 2018. Consideration of the use of 2018 is taken to facilitate the recording of information on respondents, namely, art workers and the community working in the tourism sector in the Junjungan Ubud Village, Bali.

\section{Research Instruments}

The instrument used in this research is descriptive research through literature surveys and field surveys and in-depth interviews. Interviews conducted are open-ended questions and closed-ended questions.

\section{Data Analysis Method}

The analytical method used in this study includes several methods in accordance with the objectives of the study are as follows:

1. The Theory of Social Change from Karl Max in Yuman (2017). Theory of Social Change is a natural thing and will continue as long as humans interact and socialize. Social change occurs because of changes in elements in people's lives, both material and immaterial, as a way to maintain the balance of society and adapt to the development of a dynamic era. For example, geographic, biological, economic, or cultural elements. Sociologists argue that social change is the main social condition that causes social change. These conditions include economic, technological, geographical or biological conditions. This condition causes changes in other aspects of social life. Social change has a steady direction through which society. All societies go through the same phase sequence and start from the initial development stage to the last development. When the final stage has been reached, the evolutionary change has ended. The most important principle of the theory of evolution is that the stages of society originate from birth, growth, and perfection. Durkheim argues that evolutionary change influences the way people regulate, especially with respect to

Merta, I. N. (2019). Social and cultural shifts on art worker community towards current globalization. International Research Journal of Management, IT and Social Sciences, 6(6), 29-36. https://doi.org/10.21744/irjmis.v6n6.746 
work. Meanwhile, according to Tonnies, people change from a simple society with close and cooperative relations, to a large type of society with special and impersonal relationships. Social change always continues to be seen from the division within society, individuals become alienated, and socio-cultural changes to individualization and the search for power.

2. The Theory of Globalization Barbara Ward in Warsono (2007). Globalization as a global process marked by the increasing loss of world borders (a borderless world: one world, different but never divide), is inseparable from the development of human thought. Changes in the world and culture, more due to the thought of the demonstration movement (Ward, 2013 in Warsono, 2007). Economic globalization is a process of economic activity and trade, in which countries around the world become a market force that is increasingly integrated with no obstacles to the country's territorial borders (Abeng, 1997). Economic globalization requires the removal of all restrictions and barriers to the flow of capital, goods, and services. When economic globalization occurs, the boundaries of a country will become blurred and the link between the national economy and the international economy will be even tighter. Globalization of the economy, on the one hand, will open competitive market opportunities for products from domestic to international markets. Conversely, it also opens opportunities for the entry of global products into the domestic market. The industrialization has led to colonialism, nationalism, and globalization. Travel between regions in the world can be reached by aircraft technology in a very fast time. As a result, almost all regions in this part of the world are reached in a short time.

Observation Techniques, Interviews, Documentation Studies

Observation is carried out by making direct observations in the field so that they can see and observe more closely about the condition of the Junjungan Ubud Bali village. In-depth interviews (In-depth Interview) with several informants that have been set by 29 people. Documentation studies, namely data collection techniques by taking over the minds of others and some past documents or records at the village office or relevant institutions.

\section{Results and Discussions}

1. The theory of social change from Karl Max in Yuman (2017). Theory of Social Change is a natural thing and will continue as long as humans interact and socialize. Social changes occur because of changes in elements in the life of the people of Junjungan Ubud, both material and immaterial, as a way to maintain the balance of the community and adjust to the dynamic times. For example, geographic, biological, economic, or cultural elements. Social change is the main social condition that causes social change. These conditions include economic, technological, geographical or biological conditions. This condition causes changes in other aspects of social life. Social change has a clear direction through the community of Junjungan Ubud Bali. All societies go through the same phase sequence and start from the initial development stage to the last development. When the final stage has been reached, the evolutionary change has ended. The most important principle of the theory of evolution is that the stages of the Junjungan Ubud Bali society originate from birth, growth, and perfection. Durkheim argues that evolutionary change influences the way people regulate, especially with respect to work. Meanwhile, according to Tonnies, people change from a simple society with close and cooperative relations, to a large type of society with special and impersonal relationships. These changes always continue to be seen from the division in society, individuals become alienated, and socio-cultural changes to individualization and the search for power. This phenomenon has hit urban communities.

Besides that, Paul B. Horton (1991), states that there are a number of weaknesses in the Theory of Evolution including the following. (1) Data supporting the determination of the stages in the Junjungan Ubud community become a series of often inadvertent stages. It can be concluded that the stages of community development are determined in accordance with the stages that are most in accordance with this theory. (2) The sequence in the development stage is not entirely assertive, because there are some Junjungan Ubud people who are able to go beyond a certain stage and go directly to the next stage, in other words passing through one stage. In contrast with before, there are also groups of people who just walk backward, not going forward as they wish. (3) His view that social change will end at its peak when the people of Ubud have achieved prosperity. Whereas conflict theory explains that conflict originates from class disputes between groups that control capital or government with materially oppressed groups, thus leading to social change. The most important source of social change in this perspective is social class conflict in the Junjungan Ubud community. This perspective has the principle that social conflict and social change are things that are always attached to the structure of society. This theory is based on Karl Marx's thought that social class conflict is the most important 
and influential source of all social change. Furthermore, Functional Theory, assumes that each element of society provides functions to other elements of society. Changes that occur in the Junjungan Ubud community will also cause changes in other parts. The concept of culture shock is explained by social change within a functional framework, although elements of the Junjungan Ubud Bali community are interconnected with one another, some elements can change very quickly, while others do not. Such delays create social and cultural divisions between rapidly changing elements and slow elements. This gap will cause social and cultural shock to the community. The last one, Cycle Theory, has an interesting perspective in seeing social change because it assumes that social change cannot be fully controlled by anyone, even skilled people. In every Junjungan Ubud Bali community there are cycles that must be followed. The rise and decline of civilization (culture) is inevitable and social change is not always good. Besides that according to Talcott Parsons and Wilbert E. Moore, theories about society and social change cannot be separated. But it must also be recognized that there is no single theory of social change that is really sufficient to read the changes that have taken place in the Junjungan Ubud Bali community, including what has been so often expressed, what is called "grand theory". Etzioni said, "grand theories" did not provide sufficient guidance for sociological research but no modern social change had replaced it. It is undeniable that when a complete theory of the Junjungan Ubud Bali community was developed, the effort was about the study of "complete structures" static "and" dynamic processes ". The concept of social change and cultural change, in general, the two concepts are distinguished, namely each change is associated with different aspects, one relating to the changing cultural field and the other with the social field. Basically, social and cultural shifts are concepts that are actually related to each other despite differences. Social shifts include changes in terms of structure and social relations, while cultural shifts include changes in terms of the culture of the people of Junjungan Ubud, Bali. Changes in the distribution of age groups, levels of education, social relations between ethnic groups living in one area, the role of women in political organizations and others are examples of social shifts. While the cultural shift includes the discovery of computer technology and the creation of modern dance and others. But both of these shifting concepts are mutually related, for example the shifting role of women in the Junjungan Ubud Bali community is related to changes in the value of women's position. So the phenomenon of a change in it will include social and cultural aspects so that the difference in terms between the two is often not given much attention.

From the discussion above it can be concluded that each Junjungan Ubud Bali community evolved through four stages of development such as human growth, namely childhood, adolescence, adulthood, old age. The most important source of social shift in this perspective is social class conflict in the Junjungan Ubud community of Bali. Social conflict and social change are things that are always attached to the structure of society. This theory is based on Karl Marx's thought that social class conflict is the most important and influential source of all social shifts. Social shift assumes that social shift cannot be fully controlled by anyone, even skilled people. Basically, social and cultural shifts are concepts that are actually related to each other despite differences. Social shifts include shifts in terms of structure and social relations, while cultural shifts include shifts in terms of the culture of the people of Junjungan Ubud, Bali. Shifts in the distribution of age groups, levels of education, social relations between ethnic groups living in one area, the role of women in political organizations and others.

2. The Theory of Globalization Barbara Ward in Warsono (2007). The industrialization has led to colonialism, nationalism, and globalization. Travel between regions in the world can be reached by aircraft technology in a very fast time. As a result, almost all regions in this part of the world are reached in a short time. Intensive cultural globalization occurs with the development of communication technology. Contact through the media replaces physical contact as the main means of international communication. Various features of cultural globalization can be observed with the development of international cultural exchanges, the development of tourism and tourism as well as the increasing number of people immigrating from one country to another. Echoes of globalization have made the world community, even the people of Junjungan Ubud Bali get ready to accept the reality of the entry of external influences on all aspects of life. One aspect that is affected is culture. Associated with that culture can be interpreted as the values (values) that are embraced by the community or perceptions held by citizens of various things. Culture can also be defined as a form, which includes ideas or behavior, behavior, and results of behavior, and it is manifested in traditional arts (Koentjaraningrat, 1961). In this connection, both values and perceptions, are related to psychological or psychological aspects, that is, what is in the mind. These aspects of the psyche become important when it is realized that a person's behavior is greatly influenced by what is in his mind. As one of the results of one's thoughts and inventions is art, which is a subsystem of culture. For the people of Junjungan, Ubud, the cultural aspect is one of the strengths that has a variety of rich values, including the arts. Folk art, one part of culture is not immune to the influence of globalization. Globalization in culture can develop quickly. This is certainly influenced by the speed and ease in obtaining access to communication and news. However, this would backfire itself and become the most crucial or

Merta, I. N. (2019). Social and cultural shifts on art worker community towards current globalization. International Research Journal of Management, IT and Social Sciences, 6(6), 29-36. https://doi.org/10.21744/irjmis.v6n6.746 
important issue in globalization, namely the fact that the development of knowledge is controlled by developed countries, not developing countries. Those who have and are capable of driving international communication are in fact developed countries. As a result, developing countries are always worried that they will be left behind in the flow of globalization in various fields, such as politics, economics, social, culture, including the arts. The discourse of globalization as a process is marked by the rapid development of science and technology so that it is able to fundamentally change the world. International communication and transportation have removed the cultural boundaries of each nation. The culture of each nation tends to lead to globalization and become a world civilization so that it involves humanity as a whole. In line with the development of science and technology as cultural elements, Western culture is considered a central culture that is imitated by Eastern societies, especially in developing countries. On the other hand, Western society is also always trying to penetrate its culture to people in other countries, such as McDonaldization. The family of the Junjungan Ubud community has no power to withstand the current of globalization with various buzz that attracts consumers, both goods and services, packaged very elegantly which is propagated by the media attracting potential customers. The ongoing development of globalization has led to cultural contacts between countries. The opening of one country to another, not only goods and services, but also technology, consumption patterns, education, cultural values, and so on. The concept of globalization refers to the narrowing of the world in incentives and increased awareness of the world, namely the increasing global connections and understanding of those connections. The current globalization has had an impact on the development of the Junjungan Ubud community. The rapid flow of information and telecommunications turned out to cause a tendency that led to the waning of cultural preservation values. The development of the three $\mathrm{T}$ (transportation, telecommunications, and technology) resulted in a reduced desire to preserve the culture of one's own country. The culture of the Junjungan Ubud community that was once friendly, mutual cooperation, and politely replaced with western cultures, such as promiscuity. In the past, there were still many teenagers who were interested in learning several types of Balinese dance. Nowadays as technology advances, many teenagers learn modern dance. If it is not anticipated, the culture of this area will disappear in the community, but if it is managed well, it can be cultural tourism that generates income for the government and can also become a promising employment area for the surrounding community. Another thing that is the influence of globalization is in the use of Indonesian language that is good and right. Now there is a tendency among the young people of the Junjungan Ubud community to prefer the Indonesian dialect of Jakarta, such as the mention of the words I (me) and you (you). In addition, young people often hear the use of Indonesian with mixed English, such as ok, no problem sure, and yes, even swear words (curse) even though often heard in western films are often spoken in daily life day. These words are spread through television media in films, advertisements, and soap operas. The way of dressing teenagers in the Junjungan Ubud community before upholding the norms of decency has now changed to the current fashion. There is a tendency for young women to wear minimal and tight clothing that exhibits certain body parts. This minimal culture of dress is adopted from foreign films and magazines that are transformed into television soap operas. Technological advances can be produced through tapes, VCD, and DVD art present in the midst of modern society. Transcultural events will affect the existence of local arts. Today the public is offered a variety of alternative offers that are more attractive when compared to traditional art. The presence of Wifi and the Internet has caused the family of the Junjungan Ubud community to be able to watch various entertainment shows that are global in origin from various parts of the world. Such conditions inevitably make the exclusion of traditional art from the life of the people of Junjungan Ubud which is full of meaning in the community. For example, forms of ethnic art expression, both populist and palace, are always closely related to the ritual behavior of agricultural communities. The social changes that were present as a result of the industrialization process and the market economic system as well as the globalization of information, caused the arts to start shifting towards arts with a commercial dimension. The ritual arts were eliminated and lost their function. Even so, it does not mean that all traditional arts just disappear. There are various arts that still show their existence, even creatively continue to develop without having to be suppressed by the process of modernization and globalization.

From the above explanation, it can be concluded that globalization is a phenomenon in the family civilization of the Junjungan Ubud community which continues to move in a global society and is part of the global process. The presence of information technology and communication technology accelerates the process of globalization. Globalization touches all the important aspects of life. Globalization creates new challenges and problems that are answered and solved in an effort to utilize globalization for the benefit of life. The discourse of globalization as a process is marked by the rapid development of science and technology so that it is able to fundamentally change the world. In this globalization there is an understanding of the loss of one situation, namely the various movements of goods and services between countries throughout the world can move freely and openly in trade. The presence of Wifi and the Internet has caused the family of the Junjungan Ubud community to be able to watch various entertainment 
shows that are global in origin from various parts of the world. Such conditions inevitably make the exclusion of traditional art from the life of the people of Junjungan Ubud which is full of meaning in the community. The forms of ethnic art expression, both populist and palace, are always closely related to the ritual behavior of agricultural communities. Social changes that come as a result of the industrial process.

\section{Findings}

Findings from the results of this study about the social and cultural shifts of the people of Junjungan Ubud Bali are art product innovation. Innovation is divided into discovery and inventions, both are not a single action but the transmission of a set of elements. This means that the more cultural elements produced by the inventors, the greater will be a series of discoveries and inventions.

\section{Conclusion}

First, the most important source of social shifts in Junjungan Ubud Bali in this perspective is social class conflict in the community, that social conflicts and social shifts are things that are always attached to the structure of society. Social class conflict is an influential source of all social shifts. Each element of the Junjungan Ubud Bali community gives a function to the elements of the surrounding community. Changes that occur in the Junjungan Ubud community will also cause changes in civilization in other parts.

Secondly, Globalization is a phenomenon in human civilization as well as the Junjungan Ubud Bali community which continues to move in a global society and is part of the global process. The presence of information technology and communication technology accelerates the process of globalization. Globalization touches all the important aspects of life. Globalization creates new challenges and problems that are answered and solved in an effort to utilize globalization for the benefit of life. The discourse of globalization as a process is marked by the rapid development of science and technology so that it is able to fundamentally change the world. In this globalization contained an understanding of the loss of a situation, namely the various movements of goods and services between countries throughout the world can move freely and openly in the trade of goods and services.

\section{Conflict of interest statement}

The author declared that they have no competing interest.

Statement of authorship

The author has a responsibility for the conception and design of the study. The author has approved the final article.

Acknowledgments

We thank the editor of IRJMIS for their valuable time.

Merta, I. N. (2019). Social and cultural shifts on art worker community towards current globalization. International Research Journal of Management, IT and Social Sciences, 6(6), 29-36. https://doi.org/10.21744/irjmis.v6n6.746 


\section{References}

Abeng, T. (1997). Business ethics in Islamic context: Perspectives of a Muslim business leader. Business Ethics Quarterly, 7(3), 47-54.

Aditya, A. G. D., \& Kusuma, M. G. W. (2019). The effect of tri hita karana culture in relationship between work stress and internal auditor performance. International Research Journal of Management, IT and Social Sciences, 6(2), 72-78. https://doi.org/10.21744/irjmis.v6n2.610

Aini, Z. (2017). The actualization of cultural elements in novel Guru Onyeh by Salman Faris. International Journal of Social Sciences and Humanities, 1(3), 17-27. https://doi.org/10.29332/ijssh.v1n3.49

Fitriani, N. (2017). Perubahan sosial budaya masyarakat: studi kasus industri sepatu dan sandal di kampung Sindang Barang, Desa Pasir Eurih, Kecamatan Taman Sari, Kabupaten Bogor.

Horton, P. B., Leslie, G. R., \& Larson, R. F. (1991). The sociology of social problems. Pearson College Division.

Jain, P., Billaiya, R., \& Malaiya, S. (2017). A correlational analysis of academic stress in adolescents in respect of socio-economic status. International Journal of Physical Sciences and Engineering, 1(1), 68-71. https://doi.org/10.21744/ijpse.v1i1.14

Koentjaraningrat. (1961). Some Social-anthropological Observations on" gotong Rojong" Practices in Two Villages of Central Java. Cornell univ..

Lindayani, L. R., Masri, F. A., Idul, R., \& Sawali, L. (2018). A metaphorical analysis of Kabhanti Modero to show Munanese social relations. International Journal of Linguistics, Literature and Culture, 4(2), 72-80.

Qomarudin, A. (2010). Correlation between extraversion personality and english writing skill (Doctoral dissertation, University of Diponegoro).

Ward, D., \& Taetle, R. (2013). Barbara Newton, Margaret Breslin, Michael Mullen. Platinum and Other Metal Coordination Compounds in Cancer Chemotherapy, 433.

Warsono King, D. J., Ozveren, C. S., \& Bradley, D. A. (2007). Economic load dispatch optimization of renewable energy in power system using genetic algorithm. IEEE Proc. Power Tech. Lausanne, 1, 2174-2179.

Wirawan, I. W. A. (2018). Maintaining social relationship of Balinese and Sasak ethnic community. International Journal of Social Sciences and Humanities, 2(1), 92-104. https://doi.org/10.29332/ijssh.v2n1.96 